\title{
Behavioral state and the premature's readiness performance to begin oral feeding
}

\author{
Cristina Ide Fujinaga ${ }^{(1)}$ \\ Sabrina Maltauro(2) \\ Suzelaine Taize Stadler ${ }^{(1)}$ \\ Eleidiele Rosa Cheffer(3) \\ Sidelisa Aguiar(4) \\ Nelma Ellen Zamberlan Amorin ${ }^{(5)}$ \\ Cleomara Mocelin Salla ${ }^{(1)}$
}

(1) Universidade Estadual do Centro-Oeste, Irati, Paraná, Brasil.

(2) Consórcio Intermunicipal de Saúde de Irati, Irati, Paraná, Brasil.

(3) Associação de Pais e Amigos dos Excepcionais, Laranjeiras do Sul, PR, Brasil.

(4) Clínica de Órtese e Prótese, Universidade Estadual do Centro-Oeste, Guarapuava, Paraná, Brasil.

(5) Hospital de Clínicas da Faculdade de Medicina de Ribeirão Preto, Universidade de São Paulo, Ribeirão Preto, São Paulo, Brasil.

Research support source: Fundação Araucária.

Conflito de interesses: inexistente

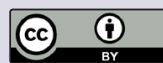

Received on: April 1, 2017

Accepted on: November 21, 2017

Mailing address:

Cristina Ide Fujinaga

Departamento de Fonoaudiologia

- UNICENTRO

PR153 Km 7, Riozinho

CEP: 84500-000 - Irati, Paraná, Brasil

E-mail: cifujinaga@gmail.com.br

\section{ABSTRACT}

Objective: to evaluate the influence of behavioral states on the readiness of the premature infant to initiate breastfeeding.

Methods: the study was transversal, observational and descriptive with 51 premature infants, attended at the Neonatal Intensive Care Unit (NICU), from a Baby-Friendly Hospital. The infants were evaluated using the «Preterm Oral Feeding Readiness Assessment Scale». The evaluation occurred close to the feeding time and was performed in preterm infants in two behavioral states, in deep sleep and alertness. Thus, preterm infants were self-controlled. For the data analysis, the T-Test and the McNemar Test were applied, with a significance level of 0.05 .

Results: there was a statistically significant difference in the behavior of premature infants in alert behavior and deep sleep. In the alert state, preterm infants showed greater readiness for oral feeding in the breast. The results highlight the importance of the behavioral state of prematurity for professionals working in NICUs.

Conclusion: the behavioral state influences the beginning of premature infant feeding. The alertness behavioral status of premature infants is essential during neonatal speech therapy assistence.

Keywords: Breast Feeding; Sucking Behavior; Consciousness; Infant, Premature;Speech, Language and Hearing Sciences 


\section{INTRODUCTION}

Breastfeeding is the most effective and efficient way to promote maternal and child health and its benefits are widely reported in the literature ${ }^{1}$. The promotion of breastfeeding occupies a prominent position in policies and initiatives dedicated to improving newborn care and maternal and child health, especially for preterm infants ${ }^{2}$. It is emphasized that the process of breastfeeding the premature infant is quite unique, requiring from the health team a very intense effort to make breastfeeding possible ${ }^{3}$. Historically, the initiation of breastfeeding in preterm infants is determined by isolated physical criteria, such as weight or gestational age, which do not represent the readiness of the preterm infant to start oral feeding 4 .

In this sense, the "Preterm Oral Feeding Readiness Assessment Scale" (POFRAS) was developed, which is divided into categories: corrected age, state of behavioral organization, oral posture, oral reflexes and non-nutritive sucking. In the evaluation is given a score of 0 to 2 for each item of each category, and at the end of it, the sum can vary from 0 to 36 points 5 .

The behavioral state is an extremely important item to verify the feeding efficiency of the baby, since it is necessary, besides craniofacial completeness, muscular contraction ability, posture, global flexion and alertness ${ }^{6}$. In this way, clinical conditions such as internal and external stability influence the behavioral state, being considered a determinant factor for stability and suction rhythm ${ }^{7}$.

Behavioral aspects may influence the readiness of the preterm newborn to begin oral feeding ${ }^{7}$. Thus, the aim of the present article was to evaluate the influence of the behavioral study on the readiness of the premature infant to initiate oral feeding in the mother's womb.

\section{METHODS}

The project was approved by the Research Ethics Committee of Universidade Estadual do Centro-Oeste do Paraná - UNICENTRO, approval number 243203. The participating mothers signed the Free and Informed Consent Form.

It is a cross-sectional, observational and descriptive study. The sample of this study consisted of 51 premature babies, assisted in the Neonatal Intensive Care Unit of a Baby-Friendly Hospital. Data were collected for six months. Inclusion criteria were: corrected gestational age equal to or greater than 30 weeks, or equal to or less than 36 weeks and 6 days; clinical stability; absence of facial deformities, respiratory, cardiovascular, gastrointestinal and neurological disorders or syndromes that impede or hinder oral feeding. The criterion for the application of POFRAS was that the infant was premature to be clinically stable, with a medical indication on the chart.

The unit has not instituted the kangaroo method, due to which the same was not performed. All mothers consented to participate in the research, but they were not always present during data collection, due to the characteristic of the unit, in which the mother does not spend the entire period with the baby.

POFRAS is an instrument developed to evaluate the readiness of the preterm infant to initiate oral feeding in the mother's womb ${ }^{4,5}$. It consists of 18 items, distributed in domains: corrected age, state of behavioral organization (state of consciousness, posture and overall tone), lip and tongue posture, oral reflexes (search reflex, suction, bite and vomit), non-nutritive suction (movement and cannulation of the tongue, movement of the mandible, bud and suction rhythm, rhythm maintenance, maintenance of the alert state) and signs of stress. It should be mentioned that the evaluation of non-nutritive sucking was performed with a minimum gloved finger. The evaluation criteria for each item followed strictly the instructional guide of POFRAS ${ }^{4,5}$.

The researcher received training by the author of the instrument used for the application of POFRAS.

POFRAS was applied by the same researcher in all preterm infants, about fifteen minutes before receiving the diet by orogastric tube, in the evening period according to the routine of the hospital, with the premature baby being accommodated inside the incubator, it is emphasized that all the premature infants were feeding via catheter. The mother was present during the evaluation. In the present study, preterm infants were self-controlled. At first, POFRAS was applied with prematurity in deep sleep. In a second moment, the POFRAS was applied with the premature one in alert condition.

In the moments of the evaluations mothers were not always present; therefore, the stimuli to wake up the babies were given by the examiner, as foreseen in the application of the instrument.

As it is an instrument of readiness of the premature to begin oral feeding, at the moment of the evaluation, all the infants were receiving feeding by orogastric tube, and feeding was not initiated in the womb. Premature infants were not receiving speech therapy at the time of data collection. 
During the evaluation, the baby was placed in the lateral decubitus position to see if he held such a position. Once this was done, the posture and the overall tone were evaluated. After that, the observation of the oral reflexes and the behavior of the premature infant during the evaluation of the non-nutritive suction were performed. It should be mentioned that in this first moment, all the babies participating in the study were evaluated in the state of deep sleep. The evaluation of non-nutritive sucking was performed for one minute, as foreseen in the evaluation instrument.

After this evaluation, stimulation was performed so that the premature baby woke up. Auditory stimuli (call the baby by name), visual (eye-to-eye contact) and tactile stimuli (touches on the face and body of the baby) were performed.

After the baby woke up, a new evaluation was performed, with the same instrument applied; the same procedure was applied in the deep sleep state, but now with the premature baby on alert. Regardless of the result of POFRAS, the baby was not placed in the womb.
Data were analyzed using the SPSS statistical program, version 19. The results were grouped in tables and analyzed statistically. The T-Test and the McNemar Test were applied, with a significance level of 0.05 .

\section{RESULTS}

In this study, 51 premature infants were evaluated, 30 being males and 21 females. The mean gestational age was approximately 32 weeks, ranging from 24 to 35 weeks. The postnatigual age of preterm infants ranged from 4 to 44 days, with an average of 21 days. Corrected age ranged from 33 weeks to 36 weeks and 6 days, with a mean of 35 weeks.

The following are the POFRAS items obtained by premature infants during the deep and alert sleep state. It should be mentioned that some items did not change in the different behavioral states, being corrected age, global posture, sucking reflex, bite reflex, vomit reflex, suction by pause and maintenance of the alert state.

Table 1 shows the distribution of preterm infants according to the overall POFRAS score. 


\begin{tabular}{|c|c|c|c|c|c|c|c|}
\hline Item of POFRAS & \multicolumn{3}{|c|}{ Premature infant in deep sleep } & \multicolumn{3}{|c|}{ Premature infant in alertness } & Value of $p$ \\
\hline \multirow{2}{*}{ Reflection of demand } & Absent & \multirow{2}{*}{$\begin{array}{c}\text { Frail } \\
1\end{array}$} & Present & Absent & Frail & Present & \multirow{2}{*}{$<0,01$} \\
\hline & 43 & & 7 & 1 & 6 & 44 & \\
\hline \multirow{2}{*}{ Suction force } & Absent & Weak & Strong & Absent & Weak & Strong & \multirow{2}{*}{$<0,01$} \\
\hline & 31 & 8 & 12 & 3 & 14 & 34 & \\
\hline \multirow{2}{*}{ Suction reflex } & Absent & \multirow{2}{*}{$\begin{array}{c}\text { Frail } \\
7\end{array}$} & Present & Absent & Frail & Present & \multirow{2}{*}{ ** } \\
\hline & 27 & & 17 & 1 & 0 & 50 & \\
\hline \multirow{2}{*}{ Language movement } & Absent & Altered & Adequate & Absent & Altered & Adequate & \multirow{2}{*}{$<0,01$} \\
\hline & 29 & 2 & 20 & 3 & 3 & 45 & \\
\hline \multirow{2}{*}{ Rhythm maintenance } & Absent & Arrhythmic & Rhythmic & Absent & Arrhythmic & Rhythmic & \multirow{2}{*}{$<0,01$} \\
\hline & 31 & 9 & 11 & 5 & 28 & 18 & \\
\hline \multirow{2}{*}{ Language cancellation } & \multirow{2}{*}{\multicolumn{2}{|c|}{$\begin{array}{c}\text { Absent } \\
24\end{array}$}} & \multirow{2}{*}{$\begin{array}{c}\text { Present } \\
27\end{array}$} & \multicolumn{2}{|c|}{ Absent } & Present & \multirow{2}{*}{$<0,01$} \\
\hline & & & & 3 & & 48 & \\
\hline & Abser & & Present & Abser & & Present & \\
\hline Vlandible movement & 29 & & 22 & 3 & & 48 & $<0,01$ \\
\hline Overall tonnare & Hyperto & & ormotonia & Hyperto & & ormotonia & 009 \\
\hline OVtrail turinaye & 2 & & 49 & 7 & & 44 & $0,0 J$ \\
\hline & High & & Plane & High & & Plane & \\
\hline Language posture & 14 & & 37 & 9 & & 42 & 0,19 \\
\hline & Up to & & Absent & Up to & & Absent & \\
\hline Signs of stress & 20 & & 31 & 19 & & 32 & 0,81 \\
\hline & Open & Semiopen & Sealed & Open & Semiopen & Sealed & \\
\hline Posture of lips & 2 & 12 & 37 & 4 & 6 & 41 & 0,3 \\
\hline & Extension & Semi-flexion & Flexion & Extension & Semi-flexion & Flexion & $\star \star *$ \\
\hline Glopal Posture & 3 & 0 & 48 & 2 & 3 & 46 & $A x$ \\
\hline & $<5$ & $>8$ & 5 a 8 & $<5$ & $>8$ & 5 a 8 & \\
\hline Suction by pause & 48 & 0 & 3 & 27 & 6 & 18 & $\star \star$ \\
\hline & No & Partial & Yes & No & Partial & Yes & $\star *$ \\
\hline IVlaıntainıng alertness & 51 & 0 & 0 & 2 & 13 & 36 & ${ }^{*} \times$ \\
\hline Bite reflex & Absent & $\begin{array}{c}\text { Present } \\
\text { exacerbated }\end{array}$ & Present & Absent & $\begin{array}{c}\text { Present } \\
\text { exacerbated }\end{array}$ & Present & ** \\
\hline & 9 & 2 & 40 & 1 & 0 & 50 & \\
\hline Reflex of vomiting & Absent & $\begin{array}{l}\text { Previously } \\
\text { presented }\end{array}$ & Present & Absent & $\begin{array}{l}\text { Previously } \\
\text { presented }\end{array}$ & Present & ** \\
\hline & 2 & 1 & 48 & 0 & 1 & 50 & \\
\hline
\end{tabular}

P value for the McNemar test; ** Test did not applied.

Caption: EC: behavioral state

Figure 1. Distribution of premature babies according to behavior in POFRAS in the state of deep sleep and alertness

Table 1. Distribution of 51 premature infants according to total score obtained in the POFRAS in the state of deep sleep and alertness

\begin{tabular}{cccccccc}
\hline $\begin{array}{c}\text { Estado } \\
\text { comportamental }\end{array}$ & $\begin{array}{c}\text { Pontuação } \\
\text { média }\end{array}$ & $\begin{array}{c}\text { Desvio } \\
\text { Padrão }\end{array}$ & $\begin{array}{c}\text { Pontuação } \\
\text { mínima }\end{array}$ & $\begin{array}{c}\text { Pontuação } \\
\text { mediana }\end{array}$ & $\begin{array}{c}\text { Pontuação } \\
\text { máxima }\end{array}$ & $\begin{array}{c}\text { Diferença } \\
\text { entre as } \\
\text { médias }\end{array}$ & Valor de $\mathbf{p}$ \\
\hline $\begin{array}{c}\text { Sono profundo } \\
\text { Alerta }\end{array}$ & 19.08 & 5.84 & 11 & 17 & 31 & 11.31 & $<0,01$ \\
\hline
\end{tabular}

T test for paired sample: statistically significant results for $\alpha=0.05$. 


\section{DISCUSSION}

As observed in the results, the behavioral state is capable of significantly influencing oral feeding, corroborating data already found in the literature ${ }^{8}$.

In a study of 20 preterm infants who were born with gestational ages of 27 to 34 weeks and who started oral feeding between 33 and 38 weeks of corrected age, the effects of the behavioral state on the effectiveness of breastfeeding were verified. The results showed that from these 20 babies, nine remained alert during breastfeeding and also were skilled and successful at breastfeeding ${ }^{9}$, and the 11 babies who fell asleep were unable to complete the suck successfully. In another study with 48 preterm infants with low weight, breastfed, the data showed that the behavioral state is a significant variable for nutritive suction and the motherbaby bond ${ }^{10}$.

It is also worth noting that the behavioral state exerts an important influence on the sucking patterns, since in infants who started crying, at feeding, there was an increase in the number of suctions and in the time spent for swallowing ${ }^{8}$.

Thus, the state of the newborn's behavior is a determinant variable for the suction pattern and should be considered even at the moment of providing guidelines to parents about the newborns' feeding ${ }^{10}$.

The importance of the behavioral state for the search reflex is also observed. The search reflex is an important behavior when considering readiness for feeding, especially relevant for demonstrating neurological integrity. The present results are lower than those found in another study, possibly due to methodological differences ${ }^{10}$.

In another finding in the literature ${ }^{11}$, we find results that also differ from the present study. In the mentioned study, 60 preterm infants with mean gestational age of 32 weeks and 3 days and corrected age of 34 weeks were evaluated. The results showed that $55 \%$ of the infants had a reflex of missing demand and only $6.7 \%$ a present one ${ }^{11}$. This difference in results is quite controversial, including, due to the difference in the corrected gestational age of the samples, being higher in the present study.

With respect to the suction reflex, the same reasoning applied to the search reflex is inferred. When comparing the results of the present study with other findings, it is noticed that the sucking reflex was more present in the sample of the present study, most probably due to the greater corrected gestational age ${ }^{12}$.
The data of the present study are different from other studies, despite the methodological similarity used ${ }^{11,13}$, regarding the item suction force.

As for the tongue-cupping variable, similar results were found in another study ${ }^{14}$. It is worth noting that the tongue cupping item does not present adequate reliability among evaluators, thus being a difficult variable to measure.

Regarding the variables that did not have significant relevance in this present study, the overall tone presented $82.35 \%$ normotonia response in the two behavioral states. This result is confirmed by the similar study, which found a high percentage in this variable, and $95 \%$ of the late premature infants in their sample with adequate tonus were found ${ }^{15}$. Regarding tongue posture, it was verified in this study that the majority of the $62.75 \%$ of the babies presented flat tongue in the two behavioral states. This index was higher when compared with other studies with similar methodology ${ }^{11,13}$.

In the present study we found the majority with absence of the signs of stress, during the evaluation in the two behavioral states, having no response with more than three signs of stress.

This finding differs from another study, in which the signs of stress decreased, since they were absent in $31.5 \%$ in the first evaluation and $74 \%$ in the last evaluation ${ }^{13}$.

The lip posture item had no significance and was answered in $64.71 \%$ sealed lips in both behavioral states, corroborating the results of another study ${ }^{10}$. In the study, the probe was not altered.

It is worth mentioning that the evaluation of the premature baby must be performed at the time of the next feeding, as it is expected that the baby is hungry and, preferably, on alert, taking care to feed the baby in this behavioral state ${ }^{6}$.

Concern for behavioral states is of the utmost importance for professionals who observe the baby because the alert state will promote the development of the preterm newborn as well as ensure the effectiveness of breastfeeding stimulation and breastfeeding ${ }^{16}$.

From this study, it is considered that there is a discussion for the change in practices pertinent to the influence of the alert behavioral state in the readiness of the preterm to begin oral feeding. The team of professionals and family members attending the neonatal unit should consider that the alert behavioral state is imperative in the performance of the premature infant 
during the assessment of readiness and the moment of oral feeding in the mother's womb.

\section{CONCLUSION}

According to the results of this study, it can be concluded that the behavioral state influences the performance of the readiness of premature infants to initiate oral feeding. Therefore, the behavioral state must be taken into account, both at the time of the evaluation of premature infants and at the moment of breastfeeding, since in the alert state they will be able to feed themselves with greater effectiveness. Thus, the result of the present study is important to guide the conduct in the neonatal care, being the behavioral state alert essential for Speech Therapy performance.

\section{REFERENCES}

1. Quigley MA, Hockley C, Carson C, Kelly Y, Renfrew MJ, Sacker A. Breastfeeding is associated with improved child cognitive development: a population-based cohort study. J Pediatr. 2012;160(1):25-32.

2. Brasil. Ministério da Saúde. Secretaria de Atenção à Saúde. Departamento de Ações Programáticas Estratégicas. Atenção humanizada ao recémnascido de baixo peso: Método Canguru/ Ministério da Saúde, Secretaria de Atenção à Saúde, Departamento de Ações Programáticas Estratégicas. Brasília: Editora do Ministério da Saúde, 2011.

3. Gorgulho FR, Pacheco STA. Amamentação de prematuros em uma unidade neonatal: a vivência materna. Esc Anna Nery. 2008;12(1):19-24.

4. Fujinaga $\mathrm{Cl}$, Zamberlan NE, Rodarte MDO, Scochi CGS. Confiabilidade do instrumento de avaliação da prontidão do prematuro para alimentação oral. Pró- Fono R Atual. Cientif. 2007;19(2):143-50.

5. Fujinaga $\mathrm{Cl}$, Scochi CGS, Santos $\mathrm{CB}$, Zamberlan $\mathrm{NE}$, Leite AM. Validação do conteúdo de um instrumento para avaliação da prontidão do prematuro para início da alimentação oral. Rev Bras Saúde Mat Infant. 2008;8(4):391-9.

6. Lemons PK, Lemons JA. Transition to breast/bottle feedings: the premature infant. J Am Coll Nutr. 1996;15(2):126-35.

7. Bauer MA, Prade LS, Keske-Soares M, Haëffner LSB, Weinmann ARM. The oral motor capacity and feeding performance of preterm newborns at the time of transition to oral feeding. Braz $\mathrm{J}$ Med Biol Res. 2008;41(10):904-7.

8. Medoff-Cooper B, Bilker W, Kaplan JM. Sucking patterns and behavioral state in 1- and 2-day-old full-term infants. JOGNN. 2010;39(5):519-24.

9. McCain GC. Behavioral state activity during nipple feedings for preterm infants. Neonatal Netw. 1997;16(5):43-7.

10. Delgado SH, Halpern R. Amamentação de prematuros com menos de 1500 gramas: funcionamento motor-oral e apego. Pró-Fono R Atual. Científ. 2005;17(2):141-52.

11. Fujinaga $\mathrm{Cl}$, Moraes SA, Zamberlan-Amorim NE, Castral TC, Silva AA, Scochi CGS. Clinical validation of the Preterm Oral Feeding Readiness Assessment Scale. Rev Lat Am Enf. 2013;21(SPE):140-5.

12. Barros PML, Araújo CMT, Lins LCB. Atuação fonoaudiológica em bebês prétermos de mães adolescentes: uma nova realidade. Rev. CEFAC 2008;10(4):520-7.

13. Rossarolla C, Menon MH, Scochi CGS, Fujinaga $\mathrm{Cl}$. Validade discriminatória do instrumento de avaliação da prontidão para início da alimentação oral de bebês prematuros. Rev Soc Bras Fonoaudiol. 2009;14(1):106-14.

14. Neiva FCB, Leone CR. Evolução do ritmo de sucção e influência da estimulação em prematuros. Pró-Fono R Atual. Científ. 2007;19(3):241-8.

15. Kao APD, Guedes ZCF, Santos AMN. Características da sucção não-nutritiva em recémnascidos a termo e pré-termo tardio. Rev. soc. bras. fonoaudiol. 2011;16(3):298-306.

16. Silva PK, Almeida ST. Evaluation of preterm infants during the first offering of the maternal breastfeeding in a neonatal intensive care unit. Rev. CEFAC. 2015;17(3):927-35. 